\title{
PERSONAL NETWORKS ON THE LABOUR MARKET: WHO FINDS A JOB IN THE CREATIVE SECTOR IN POZNAŃ?
}

\author{
MiCHAŁ MĘCZYŃSKI \\ Institute of Socio-Economic Geography and Spatial Management, Adam Mickiewicz University in Poznań, \\ Poland
}

Manuscript received: May 18, 2016

Revised version: September 27, 2016

\begin{abstract}
MĘCZYŃSKI M., 2016. Personal networks on the labour market: Who finds a job in the creative sector in Poznań? Quaestiones Geographicae 35(4), Bogucki Wydawnictwo Naukowe, Poznań, pp. 133-143, 2 tables, 2 figs.

ABSTRACT: The spread of urban policies based on a set of standardised 'creative city' strategies has been criticised on a number of counts. In Scott's (2006: 11) view, focusing just on "creating a high-quality urban environment, rich in cultural amenities and conducive to diversity in local social life" is too limited. He points out that the relationship between the presence of creative people and the development of a city is far more complex. The research undertaken as part of the European ACRE project (Accommodating Creative Knowledge: Competitiveness of Metropolitan Regions within the Enlarged Union) has revealed that access to a diversity of creative-labour-market opportunities is vital to both attract and retain talent in the longer term. Accessible and inclusive networks of creative workers are also vital, but their importance is often overlooked. The functionality of such networks has a huge impact on the possibility of finding a new job, and can be particularly important for lowering entry barriers for newcomers in creative occupations. Here, these issues are explored on the basis of a research conducted among managers of creative firms and international creative-class migrants in Poznań (Poland). This city has recently experienced major economic restructuring and a shift from the manufacturing industry towards a more creative and knowledge-based one.
\end{abstract}

KEY WORDS: creative sector, labour market, personal networks, social ties

Michał Męczyński, Institute of Socio-Economic Geography and Spatial Management, Adam Mickiewicz University in Poznań, ul. Krygowskiego 27, 61-680 Poznań, Poland; e-mail: micmec@amu.edu.pl

\section{Introduction}

The concept of the creative class proposed by Florida (2002) concentrates on workers whose job is to create meaningful new forms. They work in the creative sector, defined as those economic activities that are based on individual creativity, skill and talent, with the potential to create wealth and jobs through the development of intellectual property (DCMS 2001). Representatives of the creative class work in specific conditions. As Morrison and Martin (2003) state, in the growing imperfect labour market the specific nature of work, the employer-employee relationship, and the process of the socio-spatial differentiation and segmentation generate non-competing and stratified submarkets and conditions of perpetual non-equilibrium (Morrison 1990). The process of the stratification of labour occurs predominantly in the creative sector. While standard work is characterised by stable, continuous and regular-pay employment, a large fraction of creative jobs are 'non-standard'. Representatives of the creative sector typically hold a temporary 
contract related to a specific project. Many of them are self-employed or hold freelance working positions (Beck 2000; Grabher 2001; Markusen 2006; Brown, Nadler, Męczyński 2010; Ibert, Schmidt 2014; Nadler 2014). The temporary, project-based nature of work precludes unionisation and requires an individual adaptation to the market and individual negotiations of working conditions (Apitzsch 2013). Such working conditions stimulate creative-sector workers to develop various individual strategies which help them to thrive on the labour market.

Two important issues arise in this context: how mobile workers in the creative sector are, and how they adapt to changes in the market conditions. As will be discussed, these issues are closely related to the way the workers interact with both pre-existing and newly formed personal networks of family members, friends, acquaintances and colleagues.

From the perspective of Florida (2002), the economic growth of the American cities, including the dynamically developing labour market, is dependent on the presence of skilled and talented people he calls the creative class. Its members tend to be highly mobile and choose places that already have a high concentration of other creative people (Talent), and are culturally diverse and open to new ideas (Tolerant), which become 'cultural capitals' wedded to new products (Technology).

Musterd and Kovács (2013) claim that in Europe members of the creative class are not so mobile, and their location choices seem to depend on different priorities which can generally be linked to a more traditional value system. They tend to value a city for its sense of history and for strong personal networks they have developed there on the basis of close personal relations with family and friends (Martin-Brelot et al. 2010).

Such personal networks are important not only for the quality of the personal life of individuals, but they can also have a great impact on the dynamics of the labour market in the creative sector (Scott 2006; Potts et al. 2008; McKinlay, Smith 2009; O'Connor 2015). They can function as sources of information about job openings and general industry trends, and also as a forum for an exchange of ideas about work and career paths (Kovács, Musterd 2013; Ibert, Schmidt 2014).
Granovetter (1973) claimed that to fully understand the impact of personal networks on both personal and professional lives of individuals, it was important to distinguish between strong relations, or ties, formed with family members and close friends, and weak ties formed with acquaintances and colleagues. His research showed that, although they were naturally limited in number, strong ties had a stronger effect on the personal sphere, while the more numerous weak ties had a greater impact on professional life. However, his research was limited to the United States and did not provide information about the possible geographical and cultural dependence of its conclusions. Moreover, the relative importance of ties of different strength for the job-market dynamics could depend on the specific sector of the economy (in our case, the creative sector), and could also differ for different categories of workers (Comunian 2011; Yakubovich 2012).

In Putnam's (1993a, 1993b) conception of social capital, its development depends on a region's path dependence. The historical legacy of a place notably affects its social relations. The discontinuity of Poland's development path under the communist system made the country unable to keep up with global processes. The introduction of the market model into the economy in 1989 has resulted in its privatisation and the appearance of entrepreneurship and competition. The former socialist economies were managed by highly hierarchical political and administrative structures that represented the totalitarian state. After the collapse of the central planning system many of those relationships transformed into personal networks and informal groups of individuals who continued to work with each other (Todeva 2000).

Following the transformation of the economic system, the creative sector started to develop in Poland as a result of two types of processes: (a) exogenous, connected with activities of transnational corporations and EU institutions; and (b) endogenous ('grass-roots'), spontaneously utilising local human capital (Stryjakiewicz et al. 2009). Employment in the creative sector in Poland kept increasing yearly, to reach more than 400,000 workers in 2014 (about 2.5\% of total employment; Eurostat 2015). The size of the creative labour force in Poland was average against East European figures, the highest being recorded in 
Estonia, at 3.1\% of the total labour force, and the lowest in Romania, at 1.1\% (Eurostat 2015).

In spite of positive changes in economic indicators in Poland during the transformation of its economic system, there appeared many groups unsatisfied with their quality of living. Rising unemployment and prices led to the social and economic exclusion of many members of society, a high level of frustration, and distrust in political élites, which discouraged people from getting involved in political and economic activity. These negative attitudes towards the economic changes that have occurred in Poland can also be noted among creative-sector representatives. This situation inclines Polish citizens to develop strong ties based on the family and close friends. The current low stock of social capital, including the quality of social relations, surprise researchers (Lasinska 2013).

There are indications that, compared with their western counterparts, in the cities of EastCentral Europe the creative-sector workers rely more on the small number of strong ties even when it comes to their professional lives. The cities in this part of Europe have been transforming rapidly together with the economic system after 1989, but the traditional values related to the closeness to the family and friends remain very important in the creative class (Kovács, Musterd 2013, Todeva 2000).

In this paper these issues are investigated through a case study of the highly flexible creative-sector labour market in one of the EastCentral metropolises of Europe - the Poznan Metropolitan Region (PMR). The author assesses the strength of ties in the personal networks of creative-class members and the importance of this strength for finding a job and more generally for prospering professionally in the creative sector. Also, a comparison is made of the behaviour of two creative-sector subgroups: managers and international migrants, who tend to generate and use different types of personal networks.

\section{Conceptual approach in the light of the literature}

According to Scott (2006: 8), personal networks of creative workers are involved in the creative process. The successful creative individuals involved in personal networks are rich in social capital, and since the correlation between the different forms of capital is strong, they also have a better chance of being rich in economic terms, i.e. holding a profitable position at work (Kovács, Musterd 2013). The issue of personal networks has thus become a topic of a prominent debate in the academic and policy circles in the European Union countries (European Agenda 2012; HM Government 2009, 2011). An important aspect of this problem is that the strength of ties in personal networks can vary between the categories of creative workers ${ }^{1}$ (e.g. managers, international migrants), who are referred to as actors in the network (Latour 2005).

Granovetter's (1974) research reveals that the strength of an interpersonal tie is a linear combination of the amount of time, the emotional intensity, the intimacy (or mutual confiding), and the reciprocal services which characterise each tie (Table 1). His conclusion is that weak ties (relations with acquaintances and colleagues) are an important resource in occupational mobility. He notes that although "strong ties have greater motivation to be of assistance and are typically more easily available (...) weak ties provide people with access to information and resources beyond those available in their own social circle" (Granovetter 1983: 209). Indeed, he found in his empirical study of the job changers that if weak ties were defined by infrequent contact around the time when the information about a new job was obtained, then professional, technical, and managerial workers were more likely to hear about new jobs through weak ties than through strong ones. In further support of this hypothesis, Montgomery (1991) incorporated network structures to analyse the effects of social networks on the labour market and evaluated the role of the weak ties, which he defined as non-frequent and transitory social relations in the labour market. He demonstrated that weak ties were positively related to higher wages and higher aggregate employment rates.

In the creative sector, the two important groups of workers are: managers of creative and knowledge-intensive companies and highly educated international migrants (Florida 2002), both

\footnotetext{
In this paper creative workers are employees of creative and knowledge-intensive firms.
} 
Table 1. Characteristics of ties in personal networks of creative-sector workers.

\begin{tabular}{|l|c|c|}
\hline \multirow{2}{*}{\multicolumn{1}{c|}{ Characteristics of ties }} & \multicolumn{2}{c|}{ Strength of ties in creative-workers' personal networks } \\
\cline { 2 - 3 } \multicolumn{1}{c}{ Type of actors } & Strong ties & Weak ties \\
\hline Type of relation & family members, close friends & $\begin{array}{c}\text { acquaintances, business partners, } \\
\text { colleagues from work }\end{array}$ \\
\hline Diffusion of information about job & informal & formal \\
\hline Origin of actors in network & low & high \\
\hline Period of living in city & city & other locations \\
\hline Position of actors at working place & long time & high \\
\hline Frequency of contacts & low & non-frequent \\
\hline
\end{tabular}

Source: author's compilation based on Granovetter (1974).

often engaged in complex problem solving that involves a great deal of independent judgement and creativity and requires a high level of education and/or social ability to interact during the creative process (Amabile 1983; Amabile, Pillemer 2012; Shaw et al. 2008; Shaw et al. 2012; Kindler et al. 2015; Perry-Smith, Mannucci 2015). Both categories of workers use strong and weak ties to succeed in the highly unstable labour market of the creative sector.

The importance of the ability of a creative manager to establish dense personal networks is discussed in Musterd and Kovács (2013). They state that there is a consensus that entrepreneurs are persons who are ingenious and creative in finding ways to increase their wealth, power and prestige, but they are not lone individuals who rely primarily on their own efforts and talents. The process of starting a new business is eminently social, as information and resources are to a large extent acquired through personal networks (Stam 2009). An example of this is highlighted in Dodgson's paper (2011) on Josiah Wedgwood. Wedgwood is a quintessential Schumpeterian entrepreneur and manager who effectively exploited both strong and weak ties. His example shows that creative managers mostly exploit formal personal networks to find a good contract to manage their firms and to sustain or increase the number of highly skilled employees (Stryjakiewicz et al. 2009). Moreover, creative firms do not act in isolation, and direct contacts between their managers allow an exchange of knowledge and ideas. The research on personal networks of entrepreneurs indicates that they can be critical of the process of entrepreneurial embedding (Shaw et al. 2012). Workers of the creative industries have been found to be both embedded in complex networks and adept at operating within such networks (Amabile 1983; Curran, Blackburn 1994; Shaw 2006).

In the case of highly qualified international migrants, personal networks can play a significant role in finding a new job in the country of destination, and can also provide assistance with accommodation and more generally integration into the new environment. All of these are important pull factors in the migration decision process, and Massey and Felipe (1987) as well as Boyd (1989) have formulated a new approach to the sociology of migrants on the basis of personal networks. They stress the role of migrants' relations with family members or close friends who help them to accommodate to the new place (Niedomysl 2008; Wikhall 2002). Ager and Strang (2008: 177) define those relations as social bonds, bridges and links. Using this typology, they develop a conceptual framework of what is perceived as a 'successful' integration of migrants. Various forms of social ties, networks and social capital provide what they refer to as a 'connective tissue', and relate to outcomes such as integration in employment (after Kindler et al. 2015).

All of the above processes in principle involve both strong and weak ties. However, their relative importance could depend on the geographical location. Since Granovetter and his followers focused on the USA and Western Europe, there is no information about the strength of ties in personal networks and their influence on job-market dynamics in Central and Eastern Europe, especially in cities, which concentrate representatives of the creative class. The present author's findings are that in this region strong ties play a more prominent role in the creative sector than in the western countries. 


\section{Creative sector in the case-study city and research methodology}

The research was carried out in the Poznan Metropolitan Region (PMR). It is located in the west-central part of Poland, equidistant from two capital cities: of Poland - Warsaw, and Germany - Berlin. The PMR is inhabited by about 856,000 people (GUS 2014). In the centre of the region lies its capital, Poznań, inhabited by about 565,000 people. It is one of the fastest growing cities in Poland.

The development path has left the region with a diversified economy with a dominating service sector $(70.9 \%$ of the region's gross value added in 2010), efficient institutions, a high quality of life, a rich cultural milieu (especially in the field of music and dance), and the tradition of entrepreneurship and high work standards (Stryjakiewicz et al. 2009; Stryjakiewicz et al. 2010). The discontinuity of the development path of Poznań under the command economy has serious implications for the structure of its social capital, particularly personal-network building in the creative sector. The region is highly homogeneous with only $0.5 \%$ (2.8 thous.) of foreign-born population (GUS 2015). Therefore, the local creative economy develops mainly thanks to entrepreneurs from Poznań, who have well-developed personal networks which link them emotionally with the region. This ethnically homogeneous business and a monthly wage below the EU average $(885$ euros in Poznań as against 1,681 euros in the EU; Sedlak \& Sedlak 2015) do not attract many foreign entrepreneurs to live and work in the city, but do not discourage creative individuals from Eastern Europe, in particular from Ukraine. The number of immigrants from this country doubled in Poznań in 2014 (with the total number of immigrants rising by 30\%; Fakty i liczby 2015). Ukrainians usually escape from territories involved in the Russian-Ukrainian conflict. Most of them follow family members who came to Poland earlier (Stryjakiewicz et al. 2009). The location of Poznań and its economic prosperity seem to offer opportunities for creative entrepreneurs linking Eastern and Western Europe.

The analysis in this paper is based on the results of a research carried out under the international ACRE project (Accommodating Creative
Knowledge. Competitiveness of the European Metropolitan Regions within the Enlarged Union). The research was conducted in the period 2006-2010 and its aim was to assess the impact of the emerging creative class and the rising creative industries on the competitiveness of EU metropolitan regions ${ }^{2}$.

The methodological approach used in the project integrated quantitative and qualitative research methods. This paper presents the results of the qualitative analysis, which was based on individual in-depth interviews. A total of 50 persons were interviewed, including 20 managers of the creative sector. They worked in creative firms aggregated in two subsectors: (1) creative industries (creative parts of computer gaming, software development, electronic publishing, software consultancy and supply, motion pictures, video activities, radio and TV activities, and advertising - NACE codes 722, 921, 922 and 744), and (2) knowledge-intensive industries (law, accounting, book keeping, auditing, finance, R\&D, higher education - NACE codes 741, 65, 73 and 803).

The selection of interviewees was made on the basis of the relative importance of companies for the particular sub-sector. The interviews were held in creative firms with top-ranking management representatives, e.g. the chairman of the board, director, or owner. All the interviewees had their own experience of business operation in the creative and knowledge-intensive sector. Therefore, the opinions collected were those of people with a practical and decisive influence on a firm's performance. Additionally, 25 international migrants and 5 experts dealing with the migration of creative individuals were interviewed. The interviews were conducted in March 2008 and March 2009. A detailed description of the sample-group selection for the survey and the indepth interviews within the ACRE framework is presented in Stryjakiewicz and Męczyński (2010). The knowledge about the creative managers and

2 The project was funded under the Sixth Framework Programme of the EU; scientists from 13 metropolitan regions in Europe participated in it (Amsterdam, Barcelona, Birmingham, Budapest, Dublin, Helsinki, Leipzig, Milan, Munich, Poznań, Riga, Sofia, and Toulouse). The team from Adam Mickiewicz University in Poznań was headed by Prof. Tadeusz Stryjakiewicz (www.acre.socsci.uva.nl 2013). 
migrants was enriched with the results of 10 additional interviews with creative sector managers conducted in January 2012.

\section{Results of empirical research}

\section{Strength of ties in the personal networks of creative managers}

As Stam (2009) states, the process of starting a new business is eminently social, as information and resources are to a large extent acquired through personal networks. Referring also to Scott (2006), who underlines the role of networks on local labour markets, one can say that the activity of managers of creative firms focuses on the sustainability of their development. The activity of Poznań managers is embedded in local personal networks, which might be based on the family and close friends (strong ties), or on acquaintances (weak ties). The formation of those networks takes time and is a process that depends very much on the creativity of the managers.

The results of the ACRE project and additional interviews show that strong personal ties have an important role in attracting and retaining managers from the creative and knowledge-intensive firms for a longer time in Poznań (Stryjakiewicz et al. 2009). This investigation focuses on the role of the personal networks, involving both strong and weak ties, in the search for jobs and contracts.

The post-1989 economic changes that have taken place in Poznań have led to the formation of two groups of managers. One took advantage of the ties established in the public sector prior to 1989 to open their private businesses in the early 1990s (Stryjakiewicz et al. 2009). The other group, which is of interest in this research, includes younger entrepreneurs who finished their education after the systemic change. Often gathering experience and contacts in foreign corporations, they went on to launch firms based on the new standards of doing business. According to the managers working in the creative firms, building a network that helps running a creative firm in Poznań is a long-term process and often starts even before a company is founded (Stryjakiewicz, Męczyński 2010, Stryjakiewicz et al. 2009).

"I associate Poznan with an atmosphere of business initiative, with successful business people who achieve something with a little help of their relatives or acquaintances. (...) In general, Poznań is a city with a very good atmosphere, great people, an overwhelming number of firms, enterprising people who speak a common language, and because of all that our firm exists" (Manager of a software consultancy and supply firm).

Most of the managers of knowledge-intensive firms usually assume full executive power within their companies, but cooperate with other managers in a way that can be termed coexistence: the firms, knowing the other entities in the field, do not get into each other's way, but also do not help each other too much. They only keep up contacts with each other, largely informal, to exchange general information about the market.

"A lot of my acquaintances run this sort of firms, and it is basically a sort of gentlemen's, colleagues' agreement. (...) Naturally, much depends on who you co-operate with, but here Poznan differs a bit, I think, from other cities in that people get involved in the business very seriously" (Manager of an accounting firm).

Spatial proximity in cities favours the development of various networks embracing informal contacts of managers of creative firms. Those in Poznan admit that building contacts with a business partner is to a large extent based on mutual trust and usually a so-called 'gentlemen's agreement'. Formal agreements come into play only if companies tighten contacts, so it is necessary to specify cooperation details, or if large firms, such as branches of international corporations, are involved.

"Often it is I who goes because it is also a matter of personal contact. (...)You have to have an eyeball-to-eyeball conversation because people always buy you first. (...) If there is some interest during the first meeting, then we start doing business together. At the beginning we are talking about from a couple of hundred to at least tens of thousands of zlotys, but our target is a deal for a couple of million" (Manager of a software consultancy and supply firm).

"It's not the case that every project terminates with signing a maintenance or outsourcing agreement. (...) It also depends on how big the client we are dealing with is, since as a rule in big international corporations the headquarters decide to implement the system" (Manager of a software consultancy and supply firm). 
In the case of creative firms, the respondents often emphasise that the acquisition of valuable employees is a crucial and difficult task for a manager. The most popular way of getting the right people for the job is informal contacts. Hardly any employees are found through advertisements, labour exchanges or recruitment by professional agencies; most are employed on the basis of personal recommendations. Thus, informal contacts play a leading role in the acquisition of well-educated, skilled and reliable creative workers. This conclusion was particularly prominent because the analysed firms were small or medium-sized, and were seeking a small number of well-vetted employees.

"Today about $70 \%$ of success on the market, especially in trade and services, is in fact the right people" (Manager of a motion-picture firm).

As part of the company-development strategy, the managers also tend to encourage an informal atmosphere and the formation of personal networks among their employees. In this respect the growing software and electronic-publishing sector appears to be particularly successful.

"It isn't a big company, it isn't a corporation, it is still a family firm. I try to prevent the rat race and stop any person trying to establish that atmosphere. Trust is important, especially regarding the people who shape the firm's activity. They should cooperate and understand one another well. I try to resolve all tensions, if possible in a friendly manner, sometimes in a top-down fashion. Who works 100 hours gets paid for 100 work hours, and who works 150 hours gets paid for 150 work hours" (Manager of a software consultancy and supply firm).

The research based on interviews with managers of creative and knowledge-intensive firms helped to determine the role of personal networks in the job or contract finding in small-scale creative and knowledge-intensive firms in the PMR (Fig. 1). The same interviews with the managers of the big companies did not provide enough information about the personal networks of their creative workers. However, the results of the research are relevant for the region because, according to Stryjakiewicz and Stachowiak, 96.3\% (2009) of small enterprises employ up to 9 workers in the PMR. Following Granovetter's (1974) research on the strength of weak ties, it was found that there was a relation between time and the strength of ties in the personal networks of managers in the

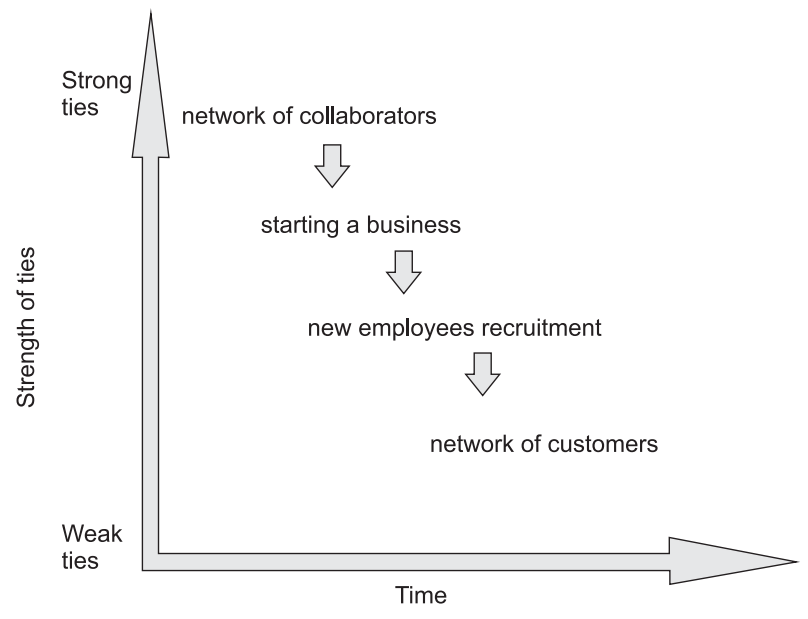

Fig. 1. Development of personal networks of managers of small creative firms.

Source: compilation based on the author's research.

creative and knowledge-intensive firms in the PMR. Since the moment of starting a business, through the development of a company and recruitment of new employees, the creative-sector managers generally exploit close relations with family and friends, and only rarely resort to acquaintances (Fig. 1). Only as the company grows and its share of the market becomes larger, weak ties may start to play an important role.

\section{Strength of ties in personal networks of creative international migrants}

The growing global mobility of creative migrants expose them to constant changes of living and working conditions. Their quality of life depends on their successful integration with the local society and finding a job in the new place. In Ager and Strang's (2008) concept of a 'connective tissue' an important role is played by social relations of migrants looking for new job opportunities. This paper focuses not only on the role of personal networks in migrants' integration with the new society, but also on strong and weak ties in those networks and their role in the migrants' search for a job.

The PMR is definitely not the first choice of international creative migrants in Poland, for many reasons, including lower wages than in Warsaw, a less stimulating cultural atmosphere than in Cracow, and lesser involvement of foreign capital in the local economy. However, the results of the ACRE project and an additional investigation indicate that there is a growing number of creative 
international migrants moving to Poznań. Most of them are sent to the city by their parent companies, offered a scholarship or a working position at one of the Poznan universities, or have decided to start their own business in the city (Stryjakiewicz et al. 2009).

For those working for an international company and intending to return to the country of origin, personal networks do not play a big role in their professional life. However, for anyone looking for a new job in Poznan, or wanting to start a business, personal networks are an important source of support.

Some of the interviewed migrants found a job with the help of relatives. Usually these were spouses who had come to the area earlier and had already found employment.

"I came to Poznan with my wife, who had worked as a piano teacher in Teatr Wielki [Grand Theatre] for the previous three years. She found the job when she found out in Lviv that the theatre needed new employees. Before I actually got the job, I had come to play concerts here" (Creative international migrant).

In other cases, weak ties of migrants that were themselves members of the creative class were helpful for finding a job. If a migrant was a unique, specially skilled expert, often an important authority or a manager of a local creative institution was also engaged in the process of his or her move to Poznań, including the arrangement of a work permit or a permanent residence status. Some of the interviewees who came to the PMR in the late 1980s or at the beginning of the social and economic transformation, stressed the important role of the authorities who invited them to Poland and helped them to settle down in the area. At the time when the systemic changes took place, most of the respondents gained support from academic institutions. An example is Adam Mickiewicz University, which provided additional bonuses to accompany the basic salary and accommodation.

"There was Rector of the university. I contacted him personally and he gave me the job" (Creative international migrant).

"I was offered the job by the Manager of Studies of Adam Mickiewicz University in Stubice" (Creative international migrant).

"In Kyoto I met a professor from Poznań and I asked him if I actually could work as a teacher of Japanese in
Poznań. That's why I came here" (Creative international migrant).

On the basis of the example of international migrants who settled in the region and have been living there for several years, one can infer that at first the number of their friends was quite great and the support they provided was bigger, but then it started to decline and only the most reliable friends were left. As the time of their stay in Poznan passed, they had to become more self-reliant, e.g. in finding a new job.

"The people I met at first are not in Poznan any more, and there is another group which is sort of in between, and it didn't last very long. I decided myself that I didn't want to (keep in contact with them any more). Then there's another group of people I've met and I have some friends among them. There aren't many of them, but they are good friends" (Creative international migrant).

The interviewees stressed that with time new perspectives emerged, often of a non-economic nature, which made them feel closer to the region. This usually involved finding a partner, getting married and having children. Along with the growing ties with the region, new working perspectives kept emerging. To some extent family duties enforced creative migrants to be more active actors on the labour market.

"I met my wife here, in this country and I have two children" (Creative international migrant).

"We met here in Poznan, and simply had jobs here, so we didn't feel compelled" (Creative international migrant).

The differences between the relevant personal networks of managers and creative migrants in Poznań can be seen by comparing Figs 1 (managers) and 2 (migrants). As in the case of creative firms' managers, the strength of ties in personal networks of international migrants has been changing in time. In contrast to the managers, who mostly rely on strong ties for business development, among the migrant workers both strong and weak ties were important in finding a job, and also for settling in the area. This kind of behaviour is in fact what one would expect from a highly skilled workforce (Florida 2002), and it is the behaviour of the managers that is more surprising and probably directly related to the cultural specificity of the geographical location. The activity of managers of creative and knowledge-intensive firms in the PMR reveals 


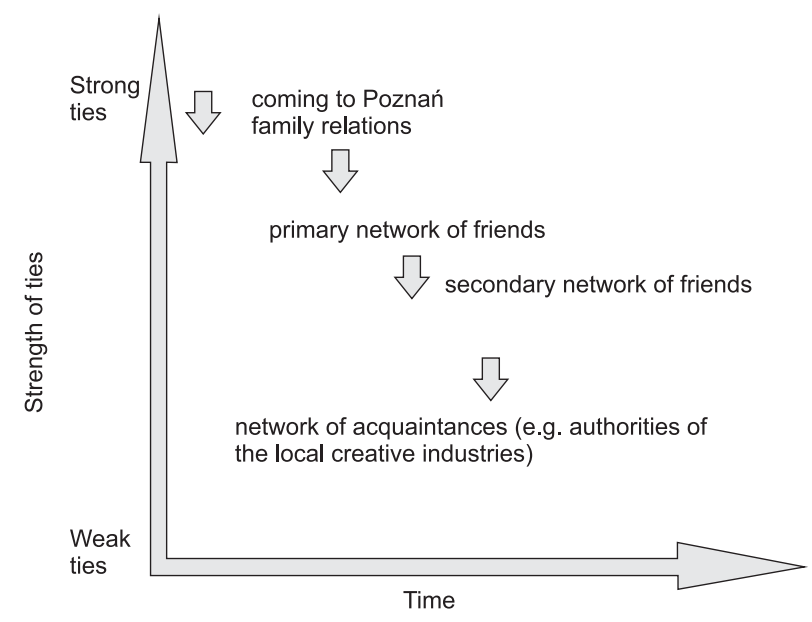

Fig. 2. Development of personal networks of creative international migrants.

Source: compilation based on the author's research.

their strong embeddedness in the local social networks. This behaviour confirms the specificity of the local community that prefers to rely on close friends and family members in business.

\section{Conclusions}

The research on the influence of the strength of ties in personal networks of creative workers and creative migrants on finding a job or a contract in the PMR sheds new light on relations among members of the creative class in one of the metropolitan regions of East-Central Europe. Previous studies of creative networks tended to focus on the role of social relations among creative workers (Perry-Smith, Mannucci 2015; Shaw et al. 2012) and institutional networks (formal clusters of creative firms and institutions Kovács, Musterd 2013; Stachowiak et al. 2013) in the creative process. This paper fills the gap related to the role of the strength of ties in networks of creative individuals. It elucidates mechanisms that determine the development in time of different relations in personal networks of managers of creative and knowledge-intensive firms and creative migrants. The results reveal several important factors (Table 2).

In the case of the managers interviewed, strong ties (family relations, close friends) played a more important role in finding a new job, a contract, or a valuable employee. The strength of those ties largely originated from the fact that most of the actors in the network were from Poznan and had known each other for a long time.

The case of creative international migrants was different, and closer to the behaviour of their counterparts in the West. Specifically, here weak ties played a significant role in finding a job.

The results of this research confirm the observations from the international ACRE project formulated by Kovács and Musterd (2013). That investigation of the motivation for choosing a metropolitan centre to live in revealed the importance of a more traditional way of living close to the family and good friends. The results confirm that proximity to family members explained not only the limited mobility of creative-class representatives, but also the possibilities of finding a job. These findings are also in line with the conclusion of Krackhardt (1992: 84) that strong ties are very important in severe changes and uncertainty: "People resist change and are uncomfortable with uncertainty. Strong ties constitute a base of trust that can reduce resistance and provide comfort in the face of uncertainty." This statement seems to be highly relevant in the case of Poznan, a city struggling with the burden of the command economy existing until 1989. The socio-economic transition affected all spheres of life, and people seem to trust more traditional

Table 2. Influence of selected characteristics of ties in personal networks of creative-sector workers on the possibility of finding a contract/job.

\begin{tabular}{|c|c|c|c|c|}
\hline \multirow{3}{*}{ Characteristics of tie } & \multicolumn{2}{|c|}{ Creative firm managers } & \multicolumn{2}{|c|}{ Creative international migrants } \\
\hline & \multicolumn{4}{|c|}{ Strength of tie } \\
\hline & Strong & Weak & Strong & Weak \\
\hline Type of actor & + & + & + & + \\
\hline Type of relation & + & + & + & - \\
\hline Diffusion of information about job & - & + & + & + \\
\hline Origin of actors of network & + & - & - & + \\
\hline Period of living in place of network creation & + & - & - & - \\
\hline Frequency of contacts & + & + & + & + \\
\hline
\end{tabular}

+ have an influence, - have no influence 
values, such as the family and close friends. However, it should be stressed that this primarily applies to managers in the city's creative sector, and to a lesser extent to international creative migrants, who are by definition less tied to a particular place and set of cultural values.

It was not possible to get a full knowledge about drivers of the personal network generation in the different subsectors (creative and knowledge-intensive) of the creative sector. Therefore, this missing aspect of the research provides a new challenge for further investigation and future research.

The results of the research bring some knowledge about the strength of ties in personal networks of creative individuals from the PMR, one of the metropolitan regions of East-Central Europe. This information should be used in the formulation of creative-sector policies at the European Union and country level. The new strategies should be tailored to the specificity of countries in this part of Europe. They represent catching-up and patching-up societies and economies still struggling with the burden of the centrally planned system existing before 1989 (Stryjakiewicz 2009). The policies should stimulate the development of formal (organisations, associations, guilds, chambers) and informal networks (internet platforms, programmes of artistic residences) to integrate representatives of the creative class.

\section{References}

Ager A., Strang A., 2008. Understanding integration: A conceptual framework. Journal of Refugee Studies 21(2): 166191.

Amabile T.M., 1983. The social psychology of creativity: A componential conceptualisation. Journal of Personality and Social Psychology 45: 357-377.

Amabile T.M., Pillemer J., 2012. Perspectives on the social psychology of creativity. Journal of Creative Behavior 46(1): 3-15.

Apitzsch B., 2013. How personal relations work: Individual market adaptation and collective action in flexible labour markets. Industrielle Beziehungen 20(2): 116-141.

Beck U., 2000. The brave new world of work. Policy Press, Cambridge.

Boyd M., 1989. Family and personal networks in international migration: Recent developments and new agendas. International Migration Review 23(3): 638-670.

Brown J., Nadler R., Męczyński M., 2010. Working on the edge? Creative jobs in Birmingham, Leipzig and Poznan. In: Musterd S., Murie A. (eds), Making competitive cities. Wiley-Blackwell, Chichester: 208-231.
Comunian R., 2011. Rethinking the creative city: The role of complexity, networks and interactions in the urban creative economy. Urban Studies 48: 1157-1179.

Curran J., Blackburn R.A., 1994. Small firms and local economic networks: The death of the local economy? Paul Chapman Publishing Ltd., London.

DCMS, 2001. Creative industries mapping document 2001 (2nd ed.). Department of Culture, Media and Sport, London.

Dodgson M., 2011. Exploring new combinations in innovation and entrepreneurship: Social networks, Schumpeter, and the case of Josiah Wedgwood (1730-1795). Industrial and Corporate Change 20(4): 1119-1151.

European Agenda for Culture, 2012. Work plan for culture 2011-2014. Working Group of EU Member States Experts (Open Method of Coordination) on Cultural and Creative Industries. European Union, Brussels.

Eurostat, 2015. Cultural employment by NACE Rev. 2 activity. Online: http://appsso.eurostat.ec.europa.eu/nui/ show.do (accessed 12 Nov. 2015).

Fakty $i$ liczby, 2015. Cudzoziemcy w Poznaniu. Online: http://www.poznan.pl/mim/s8a/news/cudzoziemcy-w-poznaniu,84920.html (accessed 30 March 2016).

Florida R., 2002. The rise of the creative class and how it's transforming work, leisure, community and everyday life. Basic Books, New York.

Grabher G., 2001. Ecologies of creativity: The village, the group, and the heterarchic organisation of the British advertising industry. Environment and Planning A 33: 351-374.

Granovetter M.S., 1973. The strength of weak ties. The American Journal of Sociology 78 (6): 1360-1380.

Granovetter M.S., 1974. Getting a job: A study of contacts and careers. Cambridge, Harvard University, Massachusetts.

Granovetter M.S. 1983. The strength of the weak ties: revisited. Sociological Theory 1: 201-233.

Główny Urząd Statystyczny, 2015. Miasta największe pod względem liczby ludności. Warszawa. Online: http://stat. gov.pl/statystyka-regionalna/rankingi-statystyczne/ miasta-najwieksze-pod-wzgledem-liczby-ludnosci (accessed 20 Feb. 2016).

HM Government, 2009. New opportunities white paper. Cabinet Office, London.

HM Government, 2011. Opening doors, breaking barriers: A strategy for social mobility. Cabinet Office, London.

Ibert O., Schmidt S., 2014. Once you are in you might need to get out: Adaptation and adaptability in volatile labor markets - the case of musical actors. Social Sciences 3: $1-23$.

Kindler M., Ratcheva V., Piechowska M., 2015. Social networks, social capital and migrant integration at local level. European literature review. IRiS Working Paper Series, Institute for Research into Superdiversity 6: 3-22.

Kovács Z., Musterd S., 2013. Personal networks. In: Musterd S., Kovács Z. (eds), Place-making and policies for competitive cities. Wiley-Blackwell, Oxford: 211-218.

Krackhardt D., 1992. The strength of strong ties: The importance of philos in organizations. In: Nohria N., Eccles R. (eds), Networks and organizations: Structure, form and action. Harvard Business School Press, Boston: 216-239.

Lasinska K., 2013. Social capital in Eastern Europe. Poland an exception? Springer Fachmedien, Wiesbaden.

Latour B., 2005. Reassembling the social: An introduction to actor-network theory. Oxford University Press, Oxford, UK. 
Markusen A., 2006. Urban development and the politics of a creative class: Evidence from a study of artists. Environment and Planning A 38: 1921-1940.

Martin-Brelot H., Grossetti M., Eckert D., Gritsai O., Kovács Z., 2010. The spatial mobility of the 'creative class': A European perspective. International Journal of Urban and Regional Research 34: 854-870.

Massey D.S., Felipe G.E., 1987. The social process of international migration. Science 237: 733-738.

McKinlay A., Smith C., 2009. Creative labour: Working in the creative industries. Palgrave Macmillan, Basingstoke.

Montgomery J.D., 1991. Social networks and labor-market outcomes: Toward an economic analysis. American Economic Review 81: 1408-1418.

Morrison P.S., 1990. Segmentation theory applied to local, regional and spatial labour markets. Progress in Human Geography 14(4): 488-528.

Morrison P.S., Martin R., 2003. Geographies of labour market inequality. In: Martin R., Morrison P.S. (eds), Thinking about the geographies of labour. Routledge, London: 3-20.

Niedomysl T., 2008. Residential preferences for interregional migration in Sweden: Demographic, socioeconomic, and geographical determinants. Environment and Planning 40: 1109-1131.

O'Connor J., 2015. Intermediaries and imaginaries in the cultural and creative industries. Regional Studies 49(3): 374-387.

Perry-Smith J.E., Mannucci P.V., 2015. Social networks, creativity, and entrepreneurship. In: Shalley C.E., Hitt M.A., Zhou J. (eds), The Oxford handbook of creativity, innovation, and entrepreneurship. Oxford University Press, New York.

Potts J., Cunningham S., Hartley J., Ormerod P., 2008. Social network markets: A new definition of the creative industries. Journal of Cultural Economics 32(3): 167-185.

Putnam R.D., 1993a. The prosperous community: Social capital and public life. American Prospect 13: 35-42.

Putnam R.D., 1993b. Making democracy work. Civic traditions in modern Italy. Princeton University Press, Princeton.

Scott A.J., 2006. Creative cities: Conceptual issues and policy questions. Journal of Urban Affairs 28(1): 1-17.

Sedlak \& Sedlak, 2015. Wynagrodzenia w Polsce na tle Unii Europejskiej w latach 1990-2013. Online: wynagrodzenia.pl (accessed 5 Jan. 2016).

Shaw E., 2006. Small firm networking: An insight into outcomes and motivating factors. International Small Business Journal 24 (1): 5-29.

Shaw E., Lam W., Carter S., 2008. The role of entrepreneurial capital in building service reputation. The Service Industries Journal 28(7): 883-898.
Shaw E., Wilson J., Grant I., 2012. Entrepreneurial embedding: Case study evidence from the creative industries. Paper presented at ISBE Conference 7-8th November, United Kingdom.

Stachowiak K., Pinheiro R., Sedini C., Vaattovaara M., 2013. Policies aimed at strengthening ties between universities and cities. In: Musterd S., Kovács Z. (eds), Place-making and policies for competitive cities. John Wiley and Sons Ltd., London.

Stam E., 2009. Entrepreneurship. In: Kitchin R., Thrift N. (eds), International encyclopedia of human geography. Elsevier, Oxford 3: 492-498.

Stryjakiewicz T., 2009. Lokalizacja firm i zachowania przestrzenne pracowników sektora informatycznego (na przykładzie poznańskiego obszaru metropolitalnego) (Location of firms and the spatial behaviour of workers of the IT sector). Prace Komisji Geografii Przemystu Polskiego Towarzystwa Geograficznego, Warszawa-Kraków 13: 21-33.

Stryjakiewicz T., Męczyński M., 2010. Atrakcyjność poznańskiego obszaru metropolitalnego dla pracujacych w sektorze kreatywnym (Attractiveness of the Poznań metropolitan region for workers of the creative sector). Bogucki Wydawnictwo Naukowe, Poznań: 1-127.

Stryjakiewicz T., Stachowiak K., 2010. Uwarunkowania, poziom i dynamika rozwoju sektora kreatywnego w poznańskim obszarze metropolitalnym (Determinants, level and growth dynamics of the creative sector in the Poznan metropolitan region). Bogucki Wydawnictwo Naukowe, Poznań: $1-135$.

Stryjakiewicz T., Burdack J., Egedy T., 2010. Institutional change and new development paths: Budapest, Leipzig, Poznan, Riga and Sofia. In: Musterd S., Murie A. (eds), Making competitive cities. Wiley-Blackwell, Oxford: 93112.

Stryjakiewicz T., Męczyński M., Stachowiak K., 2009. Poznań as a creative-knowledge region: The views of high-skilled employees, managers and transnational migrants. AMiDSt, University of Amsterdam, Amsterdam.

Todeva E., 2000. Comparative business networks in Eastern Europe. The Journal of East-West Business 6 (2): 95-129.

Wikhall M., 2002. Culture as regional attraction: Migration decisions of highly educated in a Swedish context. SISTER, Stockholm.

Yakubovich V., 2012. Getting a job as a favor in the Russian post-socialist labor market. Asia Pacific Journal of Management 30(2): 351-372. 